\title{
Pembentukan Karakter Musa di Padang Gurun Ditinjau dari Aliran Empirisme
}

\author{
Ardina Feni, Alpina Alpina, Heri Kurniawan, Monica Sardellah Daud
}

\begin{abstract}
Abstrak
Tujuan dari penulisan ini sebagai berikut: Pertama, untuk mengetahui latar belakang sebagai pemuda Kristen. Kedua, menjelaskan teori Ivan Pavlov belajar stimulus memberikan respons. Ketiga, menjelaskan pengertian teori empirisme. Metode yang dipakai dalam penulisan ini adalah Alkitab, jurnal, buku. Kesimpulan dari penulisan ini bahwa metode yang digunakan ini sebagai jembatan untuk menghubungkan antara metode mengajar dengan Alkitab. Sehingga melalui itu siswa dapat mengerti dan berperan aktif didalam kelas. Melalui cerita muda Tuhan dapat memakai siapa saja untuk menajdi alatnya karena Tuhan selalu melangkapi kapan saja dan dimana saja. Tuhan tahu apa yang menjadi pergumulan dan pergumaulan itu tidak melebihi kekuatan kita.
\end{abstract}

Kata-kata kunci: perilaku, conditional, Ivan Pavlov, pertumbuhan, rohani, karakter

\section{Pendahuluan}

Masa muda adalah masa peralihan dari kanak-kanak menuju dewasa. Pemuda adalah generasi gereja yang berperan penting. Di masa kini tidak sedikit masalah yang datang disetiap kehidupan pemuda tersebut. Tetapi setiap pemuda bisa menyelesaikan masalah itu dengan baik jika benar-benar mau belajar dari kesalahan yang dilakukan. Maka dari itu gereja harus lebih memperhatikan kaum muda saat ini, karena gereja memiliki tanggung jawab yang besar. Sangat disayangkan jika pemuda tidak memiliki hati untuk belajar dengan baik. Belajar berarti berubah. Maka diharapkan adanya perubahan perilaku pemuda yang memberikan dampak pada pertumbuhan rohaninya.

Perlu diketahui bahwa generasi muda sangat mempengaruhi kehidupan diri sendiri dan keluarga. Dalam hal ini pemuda kristen harus berhati-hati dengan zaman saat ini yang dapat membawa kehidupan menjadi tidak baik. Karena pemuda sangat mudah sekali terpengaruh dengan hal-hal yang negative jika tidak didik dnegan baik dari sejak dini. Untuk hal ini pemuda Kristen sangat diperlukan untuk terus belajar dalam meningkatkan kemampuannya.

Menurut teori Ivan P. Pavlov bahwa terjadinya suatu proses belajar itulah yang akan menjadi pengalaman belajar seseorang asalkan terus belajar tanpa berhenti. Emperisme dalam bahasa Yunani yaitu emperiskos menjadi kata (empeiria) yang berarti "pengalaman", tokoh dalam aliran ini adalah John Lock (1632 -1704) yang mengemukkan teori tentang tabularasa yang artinya manusia itu lahir dari jiwa yang kosong akan pengetahuan, oleh karena pengalamanlah yang membuat pengetahuan. Empirisme juga dikatakan sebagai pengetahuan tentang kebenaran yang sempurna dan yang tidak diperoleh akal sehat ,manusia akan tetapi suatu hal yang diperoleh dari 
pengelihatan, perasa, pedengaren bahwakan kepada sebagian tubuh manusia disini dapat dikatakan segala sesutu yang berkaitan dengan emperisme pengalaman.

Empirisme merupakan salah satu bentuk yang menetang. ${ }^{1}$ Emperisme adalah suatu doktrin filsafat yang menekankan peranan pengalaman dalam memperoleh pengetahuan dan mengecilkan peranan akal dan salah satu bentuk inovasi yang berani. Empirisme secara etimologi berasal dari kata bahsa Inggir empiricisme dan experience. Faktor bawaan dari orang tua (faktor turunan) tidak dipentingkan. Pengalaman diperoleh anak melalui hubungan dengan lingkungan (sosial, alam, dan budaya). Pengaruh empiris yang diperoleh dari lingkungan berpengaruh besar terhadap perkembangan anak. ${ }^{2}$

\section{Kajian Teori}

Dari pengalaman yang dilakukan oleh Ivan Pavlov adalah salah satu ilmuwan pertama yang menunjukkan hubungan antara rangsangan lingkungan dan respons perilaku. Pavlov secara sistematis mempresentasikan dan menarik rangsangan untuk menentukan anteseden yang memunculkan respons, yang mirip dengan cara di mana para profesional pendidikan melakukan penilaian perilaku fungsional.

Dalam ilmu pengetahuan yang paling berguna, pasti dan benar itu deperoleh orang melalui inderanya. Empirislah yang memegang peranan amat penting bagi pengetahuan, malahan barangkali satu-satunya dasar pendapat di atas itu disebut empirisme. $^{3}$

\section{Jenis Empirisme}

\section{1) Empirio-Kritisisme}

Disebut juga Machisme. Sebuah aliran filsafat yang bersifat subyaktifidealistik. Aliran ini didirikan oleh Avenarius dan Mach. Inti aliran ini adalah ingin "membersihkan" pengertian pengalaman dari konsep substansi, keniscayaan, kausalitas, dan sebagainya, sebagai pengertian apriori.

\section{2) Empirisme Logis}

Analisis logis Modern dapat diterapkan pada pemecahan-pemecahan problem filosofis dan ilmiah. Empirisme Logis berpegang pada pandangan-pandangan berikut:
a) Ada batas-batas bagi Empirisme. Prinsip system logika formal dan prinsip kesimpulan induktif tidak dapat dibuktikan dengan mengacu pada pengalaman.
b) Semua proposisi yang benar dapat dijabarkan (direduksikan) pada proposisi- proposisi mengenai data inderawi yang kurang lebih merupakan data indera yang ada seketika
c) Pertanyaan-pertanyaan mengenai hakikat kenyataan yang terdalam pada dasarnya tidak mengandung makna.

\footnotetext{
${ }^{1}$ Ratna Puspitasari," Kontribusi Empirisme Terhadap Pendidikan Ilmu Pengetahuan Sosial." Jurnal Edueksos I No 1, Januari-Juni 2012, diakses 5 Desember 2019) http://www.syekhnurjati.ac.id/jurnal/index.php/edueksos/article/view/367

${ }^{2}$ Musdalifah, "Peserta Didik Dalam Pandangan Nativisme, Empirisme, Dan Konvergensi "Jurnal Idaarah, Vol. Ii, No. 2, Desember 2018, Diakses 5 Desember 2019 journal.uinalauddin.ac.id/index.php/idaarah/article/view/243-251/pdf

${ }^{3}$ www.banjirembun.com/2012/05/makalah-empirisme.html.
} 


\title{
3) Empiris Radikal
}

Suatu aliran yang berpendirian bahwa semua pengetahuan dapat dilacak sampai pada pengalaman inderawi. Apa yang tidak dapat dilacak secara demikian itu, dianggap bukan pengetahuan.

\begin{abstract}
Alasan Mengambil Nas
Teori Ivan Pavlov tentang stimulus-respons, bahwa perubahan bisa terjadi karena adanya syarat-syarat yang harus dilakukan yang kemudia akan menimbulkan sebuah reaksi. ${ }^{4}$ Jika dihubungkan lagi dengan teori empirisme bahwa seorang bayi yang baru lahir dengan jiwa yang kosong, yang diumpamakan dengan kertas kosong yang berarti bersih. Teori empirisme mengajarkan bahwa dari pengalaman-pengalaman yang didapati dari lingkungan dan pendidikan, dari situlah perubahan mulai terjadi. ${ }^{5}$

Dalam kitab keluaran menceritakan kisah nabi Musa yang dipakai Allah untuk membawa umat Israel keluar dari tanah Mesir. Tetapi kisah ini dimulai sejak Musa lahir dari sepasang orang lewi, tetapi mereka tidak bisa merawat bayi tersebut dikarenakan pada zaman itu Firaun memberi perintah agar setiap anak laki-laki yang lahir bagi orang Ibrani harus dibunuh. Oleh karena itu mereka mengambil sebuah inisiatif untuk membuat sebuah peti untuk menaruh bayi Musa, sebab mereka tidak dapat menyembunyikan bayi Musa lebih lama lagi. Bayi musa ditaruh ditepi sungai Nil tetapi masih dalam awasan salah satu keluarga mereka. Singkat cerita bayi musa diambil oleh putri Firaun dan diasuh olehnya. Semakin hari Musa semakin dewasa dibawah didikan seorang putri, dan dalam suatu waktu Allah berfirman kepada Musa dari semak duri yang menyala tetapi semak itu tidak dimakan oleh api. Dari situlah Allah berfirman kepada Musa, supaya ia membawa umat Israel keluar dari tanah mesir. Tetapi Musa menolak karena merasa tidak mampu, musa mengemukakan berbagai alasan untuk tidak pergi (Kel. 3:11). Tetapi Tuhan memecahkan setiap alasan yang dikemukakan oleh Musa. Sehingga Musa mengikuti perintah Allah dan melakukan segala sesuatu yang diperintahkan oleh Allah kepada Musa. Ia membawa bangsa Israel keluar dari tanah Mesir dan menuntun mereka hingga mendekati tanah perjanjian.

Kelompok mengambil Kitab keluaran dengan alasan bahwa kisah Musa berkaitan dengan teori empirisme. Dimana pendidikan didapatkan dari sebuah lingkungan, oleh lingkungan akan membentuk sebuah pengalaman yang akan membawa suatu perubahan.
\end{abstract}

\section{Hubungan Nas dengan Teori}

Kisah tentang Musa ini berkaitan dengan teori yang dikemukakan oleh Ivan Pavlov, dimana ketika Musa diutus oleh Allah, sering kali juga Musa menolak. Tetapi Allah tetap mengutus Musa untuk pergi dengan sebuah jaminan bahwa Allah akan menyertai Musa. Hal ini menjelaskan bahwa ada suatu proses yang dialami Musa sebelum ia mengalami perubahan, banyak pengalaman baru yang Musa dapat. Dimana pada sebelum sebelumnya Musa adalah seorang yang pendek lidah atau tidak pandai dalam berbicara. Peristiwa Musa ini mengajarkan bahwa pengalaman adalah hal belajar

${ }^{4}$ Novi Irwan Nahar, "Penerapan Teori Belajar Behavioristik Dalam Proses Pembelajaran” Jurnal Ilmu Pengetahuan Sosial 1, (Desember 2016):86, diakses 5 Desember 2019 http://jurnal.umtapsel.ac.id/index.php/nusantara/article/viewFile/94/94 
yang terjadi secara otomatis. Dimana ketika lahir musa adalah seorang bayi yang memiliki jiwa kosong, tetapi setelah dewasa Musa mendapat pendidikan lewat pengalaman-pengalaman ketika membawa bangsa Israel keluar dari tanah Mesir.

\section{Metode}

Metode yang digunakan adalah metode kualitatif yang menjelaskan pokok permasalahan yang dihubungkan dengan nas Alkitab. Metode ini membangkitkan data yang sudah dikumpulkan oleh penulis dalam penulisan karya ilmiahnya. ${ }^{6}$ Tulisan ini juga menunjukkan bagaimana Musa memiliki kompetensi untuk menjadi pemimpin. Komptensi itu pula perlu dimiliki oleh pendidik dalam melayani mahasiswa milenial. ${ }^{7}$ Nilai-nilai karakter Musa dibentuk melalui proses kehidupan yang diubahkan dari yang lama menjadi yang baru. ${ }^{8}$ Dari perbudakan dosa kepada kemerdekaan atas dosa dengan beribadah kepada Allah. ${ }^{9}$ Model pembelajaran kooperatif berbasis media sosial ${ }^{10}$ dengan metode yang memotivasi mahasiswa untuk berubah dan meningkatkan hasil belajarnya. $^{11}$

\section{Penghubung}

Cerita musa dari sejak lahir sampai menjadi seorang pemimpin untuk bangsa Israel yang dipakai oleh Allah yang sangat luar biasa. Dapat kita lihat di dalam Keluaran 1-3. Bagamana keadaan musa sejak baru lahir hingga dewasa ia mengalami perubahan yang luar biasa khususnya ketika ia telah bernjak dewasa. Ketika Musa bertemu Tuhan dan diperintahkan untuk membawa bangsa Israel keluar dari mesir, ia merasakan panggilan Tuhan. Ketika Musa merasa bahwa Ia tidak mampu akan tetapi pada saat itulah Tuhan memakai orang-orang yang tidak mampu sama halnya seperti musa. Tuhan bekerja akan segalanya dan pada saat itulah Musa menjadi pelayanan Tuhan.

\section{Pelajaran}

Yang dimaksud dari pelajaran disini adalah setelah guru selesai menjelaskan teori kepada siswanya, guru memberikan pertanyaan kepada siswanya apakah siswa

\footnotetext{
${ }^{6}$ Hengki Wijaya dan Helaluddin Helaluddin, Analisis Data Kualitatif Sebuah Tinjauan Teori \& Praktik (Makassar: Sekolah Tinggi Theologia Jaffray Makassar, 2019).

7 Helaluddin Helaluddin dan Hengki Wijaya, "Pengembangan Kompetensi Pendidik Di Perguruan Tinggi Dalam Menyonsong Era Revolusi Industri 4.0,” 2019, https://repository.sttjaffray.ac.id/id/publications/273069/pengembangan-kompetensi-pendidik-diperguruan-tinggi-dalam-menyonsong-era-revolu.

${ }^{8}$ Hengki Wijaya, "Pengenaan Manusia Baru Di Dalam Kristus: Natur, Proses, Dan Fakta Serta Implikasi Teologis Dan Praktisnya," Jurnal Jaffray 14, no. 1 (22 Maret 2016): 109, https://doi.org/10.25278/jj71.v14i1.194.

${ }^{9}$ Tison Tison dan Jermia Djadi, "Pengajaran Tentang Ibadah Berdasarkan Surat Ibrani 10:19-25 Dan Implimentasinya Dalam Kehidupan Orang Percaya Pada Masa Kini,” Jurnal Jaffray 11, no. 1 (2 April 2013): 37-66, https://doi.org/10.25278/jj71.v11i1.67.

10 Hengki Wijaya dan Arismunandar Arismunandar, "Pengembangan Model Pembelajaran Kooperatif Tipe STAD Berbasis Media Sosial," Jurnal Jaffray 16, no. 2 (6 Oktober 2018): 175-96, https://doi.org/10.25278/jj71.v16i2.302.

11 Sifra Sahiu dan Hengki Wijaya, "Hubungan Motivasi Belajar Ekstrinsik Terhadap Hasil Belajar Psikomotorik Pada Mata Pelajaran Agama Kristen Kelas V Di SD Zion Makassar,” Jurnal Jaffray 15, no. 2 (22 September 2017): 231, https://doi.org/10.25278/jj71.v15i2.262.
} 
dapat mengerti apa yang sudah dijelaskan didepan. Apa yang bisa menjadi pelajarean dari teori ini dan cerita Alkitab yang sudah ditampilkan bersama-sama.

\section{Penerapan}

Penerapan adalah setalah kelompok menampilkan video tentang Musa. Apa yang menjadi komitmen dari semua siswa yang ada didalam kelas. Dari penerapan ini apa yang menjadikanikomitmen setiap siswa.

\section{Perubahan}

Perubahan adalah ketika seseorang mau memperbaiki semua kesalahan yang dilakukan baik dalam pola pikir dan tingkahlaku. Dari perubahan ini dapat dirasakan dan mengetahui sejauh mana seseorang dapat berubah lewat keadaan yang dialami dan bagaimana cara menyikapi hal tersebut.

\section{Penutup}

Berdoa dan Pujian. ${ }^{12}$

\section{Hasil dan Pembahasan}

Hasil dari kelompok yang sudah memperesentasikan ada dari beberapa siswa sudah menyampaikan kesaksian hidupnya secara pribadi yang masa lalu yang sangat suram sehingga membuat kehidupan merasa tiada guna lagi dan melakukan segala sesuatu hanya sia-sia. Dari beberapa siswa memiliki pengalaman hidup yang pahit dan mungkin sulit untuk dilupakan, namun ia merasakan betapa masalah itu yang dapat membawa perubahan yang nyata bagi kehidupan dirinya sekarang. Dari pembahasan ini dapat dilihat teori empirisme sangat mempengaruhi kehidupan setiap orang. Lewat kesaksian yang di alami dan di bagikan terhadap sesama dapat membawa terang Tuhan bagi sesama. ${ }^{13}$

\section{Kesimpulan}

Dari teori yang ada dan yang kelompok dapatkan bahwa dari teori empirisme ini sangat penting disetiap kehidupan manusia. Dan dari setiap presentasi dan menonton video yang sudah ditampilkan sangat membantu siswa yang ada didalam kelas untuk mengetahui, memahami dan berperan aktif didalam kelas. Bukan saja guru yang aktif, siswa akan merasakan perubahan yang ada didalam dirinya dari dulu sampai sekarng dan membuat komitmen didalam hidupnya. Seperti nabi musa yang sangat bergumul untuk menjadi seorang pemimpin bangsa Israel. Musa merasa tidak sanggup kerana tidak pandai berbicara didepan banyak orang.

12 Rohani Siahaan, "Analisis Pengaruh Nyanyian Jemaat Terhadap Kualitas Ibadah Gereja Protestan di Indonesia bagian Barat (GPIB) Jemaat Bukit Zaitun Makassar," Jurnal Jaffray 11, no. 2 (2 Oktober 2013): 140-64, https://doi.org/10.25278/jj71.v11i2.82.

${ }^{13}$ C.S Lowet, Bersaksi Dngan Mudah (Bandung: Kalam Hidup, t.t.). 


\section{Daftar Pustaka}

Helaluddin, Helaluddin, dan Hengki Wijaya. "Pengembangan Kompetensi Pendidik Di Perguruan Tinggi Dalam Menyonsong Era Revolusi Industri 4.0," 2019. https://repository.sttjaffray.ac.id/id/publications/273069/pengembangankompetensi-pendidik-di-perguruan-tinggi-dalam-menyonsong-era-revolu.

Musdalifah. "Peserta Didik Dalam Pandangan Nativisme, Empirisme, Dan Konvergensi.“ Jurnal Idaarah, Vol. II, No. 2, Desember 2018. Diakses 5 Desember 2019. https://journal.uinalauddin.ac.id/index.php/idaarah/article/view/243-251/pdf

Nahar, Novi Irwan. "Penerapan Teori Belajar Behavioristik Dalam Proses Pembelajaran.” Jurnal Ilmu Pengetahuan Sosial 1, (Desember 2016):86. Diakses 5 Desember 2019. http://jurnal.umtapsel.ac.id/index.php/nusantara/article/viewFile/94/94

Puspitasari, Ratna."Kontribusi Empirisme Terhadap Pendidikan IlmuPengetahuan Sosial.” Jurnal Edueksos I, No 1, Januari-Juni 2012. Diakses 5 Desember 2019. http://www.syekhnurjati.ac.id/jurnal/index.php/edueksos/article/view/367

Ronda, Daniel. Dasar Teologi Yang Teguh: Panduan Teologi Sistematika Di Perguruan Tinggi. Makassar: Sekolah Tinggi Theologia Jaffray Makassar, 2013.

Sahiu, Sifra, dan Hengki Wijaya. "Hubungan Motivasi Belajar Ekstrinsik Terhadap Hasil Belajar Psikomotorik Pada Mata Pelajaran Agama Kristen Kelas V Di SD Zion Makassar." Jurnal Jaffray 15, no. 2 (22 September 2017): 231. https://doi.org/10.25278/jj71.v15i2.262.

Siahaan, Rohani. "Analisis Pengaruh Nyanyian Jemaat Terhadap Kualitas Ibadah Gereja Protestan di Indonesia bagian Barat (GPIB) Jemaat Bukit Zaitun Makassar." Jurnal Jaffray 11, no. 2 (2 Oktober 2013): 140-64. https://doi.org/10.25278/jj71.v11i2.82.

Sitti Sakinah, Hengki Wijaya, Nurmadiah, Nurmadiah, Helaluddin Helaluddin. "Enhancing Students' Motivation to Learn Arabic Through Method of Muhadharah." In First International Conference on Culture, Education, Linguistics and Literature, CELL 2019. Purwokerto, Central Java, Indonesia: EAI, 2019. https://doi.org/10.4108/eai.5-8-2019.2289818.

Syawal, Syahrul, and Helaluddin Helaluddin. "Psikoanalisis Sigmund Freud Dan Implikasinya Dalam Pendidikan,” 2018.

https://www.researchgate.net/profile/Helaluddin_Helaluddin/publication/323535 054_Psikoanalisis_Sigmund_Freud_dan_Implikasinya_dalam_Pendidikan/links/ 5a9a57750f7e9be379640c45/Psikoanalisis-Sigmund-Freud-dan-Implikasinyadalam-Pendidikan.pdf.

Tison, Tison, dan Jermia Djadi. "Pengajaran Tentang Ibadah Berdasarkan Surat Ibrani 10:19-25 Dan Implimentasinya Dalam Kehidupan Orang Percaya Pada Masa Kini." Jurnal Jaffray 11, no. 1 (2 April 2013): 37-66. https://doi.org/10.25278/jj71.v11i1.67.

Wadi, Elsyana Nelce, and Elisabet Selfina. "Peran Orang Tua Sebagai Keluarga Cyber Smart Dalam Mengajarkan Pendidikan Kristen Pada Remaja GKII Ebenhaezer Sentani Jayapura Papua.” Jurnal Jaffray 14, no. 1 (March 14, 2016): 77-92. https://doi.org/10.25278/jj71.v14i1.190.

Walker, Roland. "Learning That LASTS," n.d. https://wycliffe.fi/wpcontent/uploads/2018/12/intro-to-learning-that-lasts-walker.pdf. 
Wijaya, Hengki. "Kajian Teologis Tentang Penyembahan Berdasarkan Injil Yohanes 4:24." Jurnal Jaffray 13, no. 1 (March 16, 2015): 77.

https://doi.org/10.25278/jj71.v13i1.112.

Wijaya, Hengki. "Mengapa Allah Memakai Dwight Lyman Moody? Kisah Hidup Seorang Pelayan Sekolah Minggu.” Jurnal Jaffray 10, no. 2 (October 1, 2012): 180. https://doi.org/10.25278/jj71.v10i2.52.

Wijaya, Hengki. "Pengenaan Manusia Baru Di Dalam Kristus: Natur, Proses, Dan Fakta Serta Implikasi Teologis Dan Praktisnya.” Jurnal Jaffray 14, no. 1 (22 Maret 2016): 109. https://doi.org/10.25278/jj71.v14i1.194.

Wijaya, Hengki, dan Arismunandar Arismunandar. "Pengembangan Model Pembelajaran Kooperatif Tipe STAD Berbasis Media Sosial." Jurnal Jaffray 16, no. 2 (6 Oktober 2018): 175-96. https://doi.org/10.25278/jj71.v16i2.302.

Wijaya, Hengki, dan Helaluddin Helaluddin. Analisis Data Kualitatif Sebuah Tinjauan Teori \& Praktik. Makassar: Sekolah Tinggi Theologia Jaffray Makassar, 2019.

Wijaya, Hengki. "Pendidikan Neurosains Dan Implikasinya Dalam Pendidikan Masa Kini," 2018. https://repository.sttjaffray.ac.id/media/269017-pendidikanneurosains-dan-implikasinya-d-5854b17f.pdf. 